\title{
Comparison of Colchicine Content in Gloriosa superba L., Root after Pretreatment by Thai Traditional Medicine Methods
}

\author{
Sasithorn Tandhavadhana*
}

\section{Sasithorn Tandhavadhana*}

Faculty of Science, Ramkhamhaeng University, Bangkok 10240, THAILAND.

\section{Correspondence}

\section{Sasithorn Tandhavadhana}

Faculty of Science, Ramkhamhaeng, University, Bangkok 10240, THAILAND.

Phone no: 66-81-8783135

E-mail: tuksasithornt@gmail.com History

- Submission Date: 17-03-2021;

- Review completed: 25-04-2021;

- Accepted Date: 11-05-2021.

DOI : 10.5530/pj.2021.13.121

Article Available online

http://www.phcogj.com/v13/i4

\section{Copyright}

(C) 2021 Phcogi.Com. This is an openaccess article distributed under the terms of the Creative Commons Attribution 4.0 International license.

\begin{abstract}
Introduction: In Thai traditional medical practice, the roots of Gloriosa superba L. must be treated prior to use as Thai herbal remedies. Colchicine is a major active chemical constituent in the roots. It was reported that lethal doses of colchicine were 7-26 mg. There have been two pieces of evidence that indicated 5 different pretreatment methods of Gloriosa superba L., roots. Therefore, this research aimed to compare the amount of colchicine before and after pre-treated by 5 different methods and compare colchicine content after pretreatment between methods. Methods: Provide five different locations of fresh Gloriosa superba L., roots. Each sample divided into 6 groups. The first group would be treated as a control, the second to the sixth group was pre-treated by roasting, burning, boiling, stewing, and grilling which follow the methods from two pieces of evidence. Subsequently, quantitative analysis by High Performance Liquid Chromatography. Results: The amount of colchicine in roots before and after pre-treated by roasting, burning, boiling, stewing, and grilling methods were significantly reduced by $45.61 \pm 10.61 \%(p=0.000), 37.35 \pm 14.15 \%(p=0.000), 44.55 \pm 8.60 \%$ $(p=0.000), 76.40 \pm 10.70 \%(p=0.000)$, and $30.35 \pm 11.31 \%(p=0.000)$, respectively. The stewing method was the greatest decrease amount of colchicine which significantly different from other methods. $(p=0.000)$. Conclusion: All 5 methods were significantly reduced amounts of colchicine in the roots of Gloriosa superba L. They were effective methods to pre-treat the roots of Gloriosa superba L. prior to use as Thai herbal remedies.
\end{abstract}

Key words: Gloriosa superba L., Colchicine, Pretreatment methods, HPLC, Thai traditional medicine.

\section{INTRODUCTION}

The root of Gloriosa superba L. is a materia medica used in several ailments remedies in tropical Africa and Asia ${ }^{1}$. Thai traditional medicine remedies for nasal treatment using the roots of Gloriosa superba $\mathrm{L}$. as the major ingredients ${ }^{2}$. A major active chemical constituent is colchicine (Figure 1) which has been found biological activities including anti-inflammatory, anti-bacterial, and antifungal activity. Especially, colchicine is employed in modern medicine for Gout treatment ${ }^{1}$. However, it was reported lethal doses of oral colchicine are $7-26 \mathrm{mg}^{3}$. Side effects of colchicine are nausea, vomiting, diarrhea, and abdominal pain approximately 2-6 hours after administration ${ }^{3}$. In Thai traditional medicine practice, the roots of Gloriosa superba L. must be pre-treated prior to use

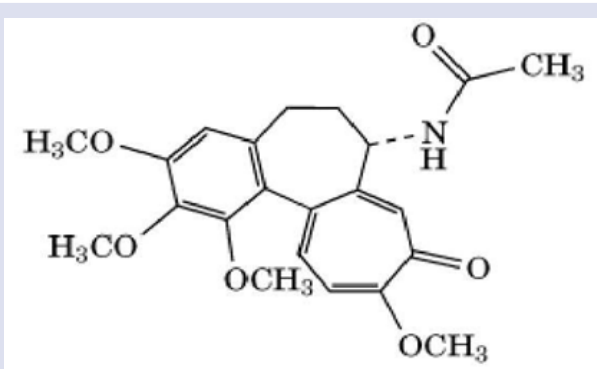

Figure 1: The chemical structure of colchicine. in compounding Thai herbal remedies. They never had evidence until 2019, a study of the colchicine content in Gloriosa superba L., root after pre-treated by 2 methods published in 2019, Mar-Apr ${ }^{4}$. The study was interviewed Thai traditional medicine experts five persons and analyzed colchicine content in 8 sources of Gloriosa superba L., roots after pre-treated by roasting and burning methods which recommended by Thai traditional medical experts. The result showed that before and after pre-treated by roasting and burning, the amount of colchicine in the roots was significantly decreased by $40.61 \pm 9.55 \% \quad(p=0.000)$ and $26.79 \pm 10.89 \%$ ( $p=0.001$ ), respectively ${ }^{4}$. In 2019 Sep, The Ministry of Public Health launched National Thai Traditional Medicine Formulary B.E.2562 which indicates three pretreatment methods of Gloriosa superba L., roots ${ }^{5}$. The pretreatment methods from previous study and National Thai Traditional Medicine Formulary B.E.2562 are different. Therefore, this research aimed to compare amount of colchicine before and after pretreatment by 5 different methods and compare colchicine content after pretreatment between methods.

\section{MATERIALS AND METHODS}

Provide fresh roots of Gloriosa superba L. from five locations, each sample divided into 6 groups. First group would be treated as a control, second and third groups were pre-treated by methods from the

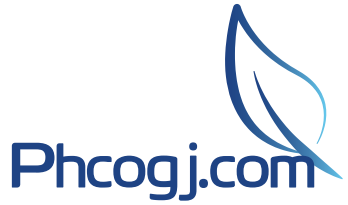

Cite this article: Tandhavadhana S. Comparison of Colchicine Content in Gloriosa superba L., Root after Pretreatment by Thai Traditional Medicine Methods. Pharmacog J. 2021;13(4): 942948. 
previous study ${ }^{4}$. The fourth, fifth, and sixth groups were pre-treated by methods from National Thai Traditional Medicine Formulary B.E. $2562^{5}$. Subsequently, colchicine was extracted and analyzed by High Performance Liquid Chromatography. This study approved by the Institutional Ethics Committee of Ramkhamhaeng University number RU-HRE 63/0057.

\section{Chemicals}

Colchicine was purchased from Sigma, methanol and acetonitrile (HPLC grade) from Merck, and methanol (AR grade) from Labscan.

\section{Plant materials}

Provided five sources of fresh Gloriosa superba L., roots from Jun 15 to Jul 20, 2020. The first, the third, and the fifth sample collected from wild population in Chonburi, Nakhonratchasima, and Prachinburi province, respectively. The second and the fourth sample purchased from a cultivated farm in Surin and Sakaeo province, Thailand. Each sample validated by compared Herbarium Specimen number K001104972. ${ }^{6}$

\section{Pretreatment methods}

Method 1, Roasting: Clean and dried Gloriosa superba L., roots at $70^{\circ} \mathrm{C}$. The dried roots $100 \mathrm{~g}$. were ground and pass through $45 \mu \mathrm{m}$ sieve. Roasted in clay pot $\varnothing 6$ inches until powder's temperature was $130^{\circ} \mathrm{C}$. The samples were taken out of the heat and cooled

Method 2, Burning: Clean and dried Gloriosa superba L., roots at $70^{\circ} \mathrm{C}$. The dried roots $70 \mathrm{~g}$. were put into a clay pot $\varnothing 10 \mathrm{~cm}$. and covered with $120 \mathrm{~g}$ of rice husks giving a 1 -inch coverage. Burning the pot and rice husks continued until the temperature at the center of the pot reached $75^{\circ} \mathrm{C}$. Then the heat was stopped but the samples continued being baked in the hot pot until the temperature at the center of the pot reached $90^{\circ} \mathrm{C}$.

Method 3, Boiling: The clean fresh roots of Gloriosa superba L. $250 \mathrm{~g}$. were put into pot $\varnothing 8$ inches. Boiled in $600 \mathrm{ml}$ of DI water for $20 \mathrm{~min}$, dried at $70^{\circ} \mathrm{C}$

Method 4, Stewing: The clean fresh roots of Gloriosa superba L. $230 \mathrm{~g}$. were put into a clay pot $\varnothing 8$ inches. Stewed with $460 \mathrm{ml}$. of honey until dry. Then cleaned the remaining honey outside of the roots and dried at $70^{\circ} \mathrm{C}$.

Method 5, Grilling: The clean fresh roots of Gloriosa superba L. 50 g. sliced into thin sheets. Grill until were lightly brown on two sides of them.

\section{Extraction of the roots of Gloriosa superba L.}

All samples were extracted in the same manner. The roots of Gloriosa superba L. were ground and pass through $45 \mu \mathrm{m}$ sieve. Take $20 \mathrm{~g}$. (accurately weighted) of each powder sample into thimble (33 x 80 $\mathrm{mm}$ ) for $200 \mathrm{ml}$ soxhlet extractor. Extraction process was continued for six hours with methanol at $60-65^{\circ} \mathrm{C}$. The solution was evaporated to dryness to get crude extract.

\section{HPLC analysis}

Each crude extract 0.250 g. (accurately weighted) dissolved in $10 \mathrm{ml}$ HPLC grade methanol in volumetric flask after that $1 \mathrm{ml}$ of stock solution was further diluted in another $10 \mathrm{ml}$ HPLC grade methanol in volumetric flask then subjected to HPLC for qualitative and quantitative analysis of colchicine and other compounds. The HPLC system consists of Shimadzu LC-20AD which was equipped with a photodiode array detector (Shimadzu SPD-M 20 A), Phenomenex Column (RP, Kromasil 5u 100A C-18, 150x4.60 mm), Guard column (Kromasil 5u 100A C-18, $2.1 \mathrm{~mm}$ ) and data were integrated by Shimadzu Class VP series software. The separation was achieved with a two-pump isocratic program for pump A and $\mathrm{B}$ (acetonitrile: $\mathrm{H}_{2} \mathrm{O}, 38: 62$ ). The flow rate was $1 \mathrm{ml} / \mathrm{min}$, runtime $10 \mathrm{~min}$, and determined at wavelength 350 $\mathrm{nm}$. Results were obtained by comparison of peak areas of the samples with the calibration curve of the referent standard. Every process was repeated 3 times.

\section{Validation method}

Linearity: The following concentration of colchicine $0.031,0.063,0.125$, $0.250,0.500$, and $0.750 \mathrm{mg} / \mathrm{ml}$ were prepared and analyzed by HPLC. Graph between concentration of standard colchicine and area under curve was plotted and calculated for linear regression.

Accuracy and precision: The concentration of colchicine 0.063, 0.250, and $0.500 \mathrm{mg} / \mathrm{ml}$ was analyzed by HPLC for only intraday precision because running time of each sample was $10 \mathrm{~min}$. Overall analysis was 15 hours. The percent recovery and relative standard deviation were calculated.

\section{Statistical analysis}

The experimental results were given as mean \pm SD. The data between before and after pretreatment were analyzed by dependent t-test. One way-ANOVA was applied followed by Scheffe Multiple Comparison test for compared between pretreatment groups. These tests were based on 2 -sided tests where $\alpha=0.05$ was considered statistically significant. All the statistical analyses were conducted using SPSS. version 17.

\section{RESULTS}

All methods of pretreatment affect to color of Gloriosa superba L., roots. After pre-treated by roasting, burning, stewing, and grilling, the color of samples was darker than the control sample. Even after boiling, the color was lighter than the control sample. Comparison of samples color from the darkest to the lightest as stewing group $>$ burning group $>$ roasting group $>$ grilling group $>$ control group $>$ boiling group, respectively. The moisture of pre-treated by roasting and burning groups compare with control group were significantly decreased $38.33 \pm 4.81 \%(p=0.000)$ and $11.40 \pm 4.06 \%(p=0.000)$, respectively. However, the moisture of boiling, stewing, and grilling groups were not significantly different from the control group. The control group extract gave dark brown oil as same as all pre-treated groups extract.

This HPLC analysis method was accepted for determination of colchicine in the roots of Gloriosa superba L. which validation method showed the coefficient of determination $\left(R^{2}\right) 0.999$ (Figure 2) and the percent recovery between $90-103 \%$. The HPLC chromatogram of referent standard colchicine showed in Figure 3. The HPLC chromatogram of the roots of Gloriosa superba L. extract before pretreatment showed in Figure 4 and after pre-treated by roasting, burning, boiling, stewing, and grilling methods showed in Figure 5-9. The retention time of colchicine appeared at $3.299 \mathrm{~min}$. The position of colchicine in HPLC chromatogram of the extract was identified by comparison of retention time. The retention time of control extract appeared at $3.300 \mathrm{~min}$ and after pre-treated by roasting, burning, boiling, stewing, and grilling extracts appeared at 3.300, 3.300, 3.295, 3.297, and $3.300 \mathrm{~min}$, respectively. The amount of colchicine in crude extract determined by comparison of the area under the curve with a calibration curve of colchicine. The average amount of colchicine in the roots of Gloriosa superba L. extract before pre-treated was $6.306 \pm 2.884$ $\mathrm{mg} / \mathrm{g}$ and after pre-treated by roasting, burning, boiling, stewing, and grilling were $3.194 \pm 1.036,3.601 \pm 0.951,3.335 \pm 1.231,1.289 \pm 0.477$, and $4.120 \pm 1.324 \mathrm{mg} / \mathrm{g}$, respectively. Comparison between before-after pretreatment, average amount of colchicine after pre-treated by roasting, burning, boiling, stewing, and grilling were significantly decreased by $45.61 \pm 10.61 \%$ ( $p=0.000), 37.35 \pm 14.15 \% \quad(p=0.000), 44.55 \pm 8.60 \%$ 


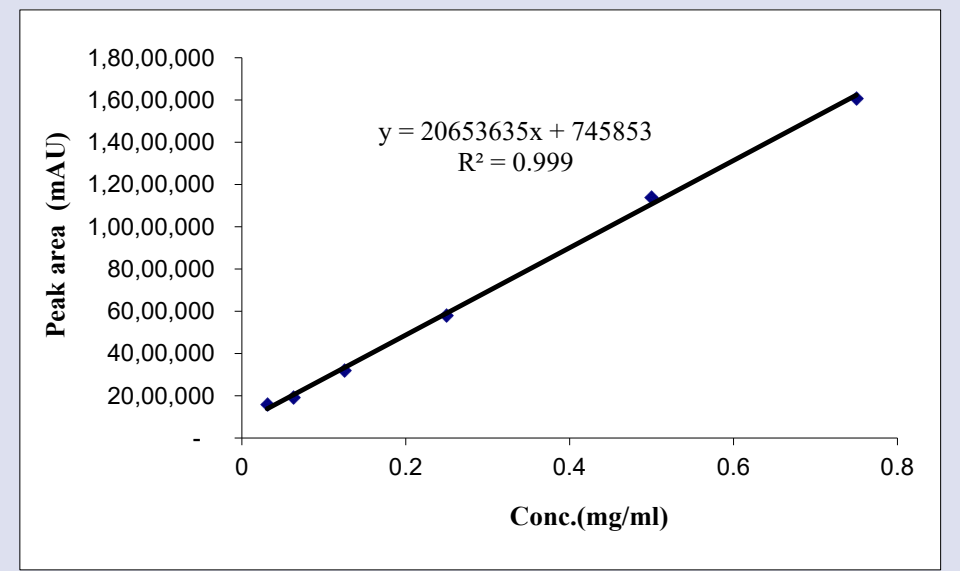

Figure 2: Calibration curve of colchicine.

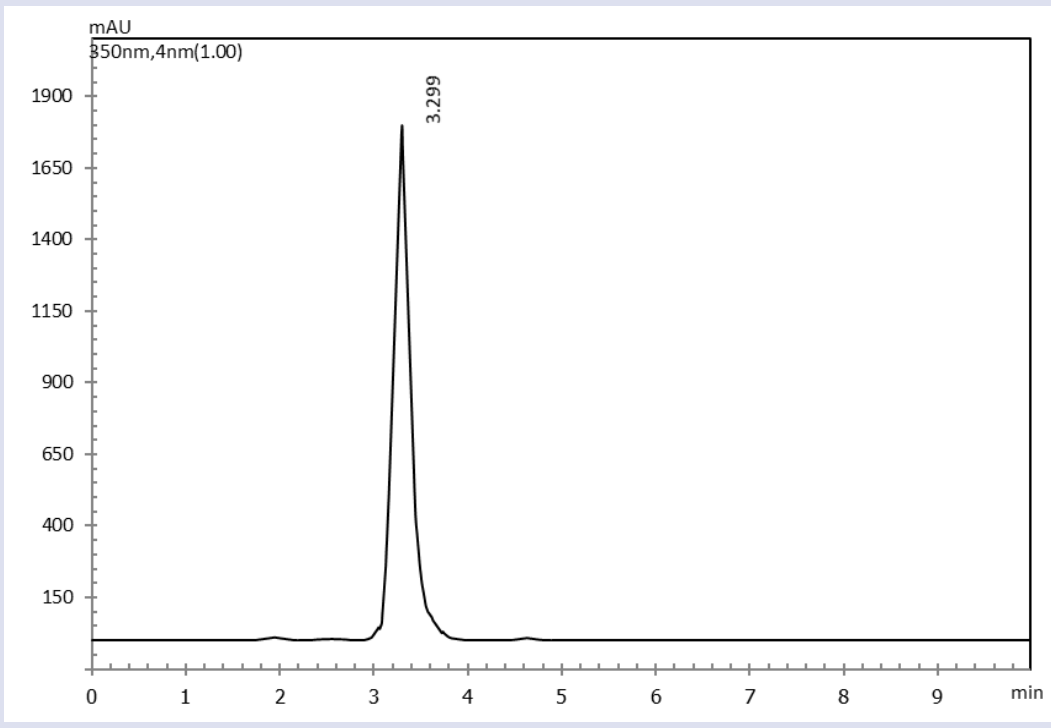

Figure 3: HPLC chromatogram of standard colchicine.

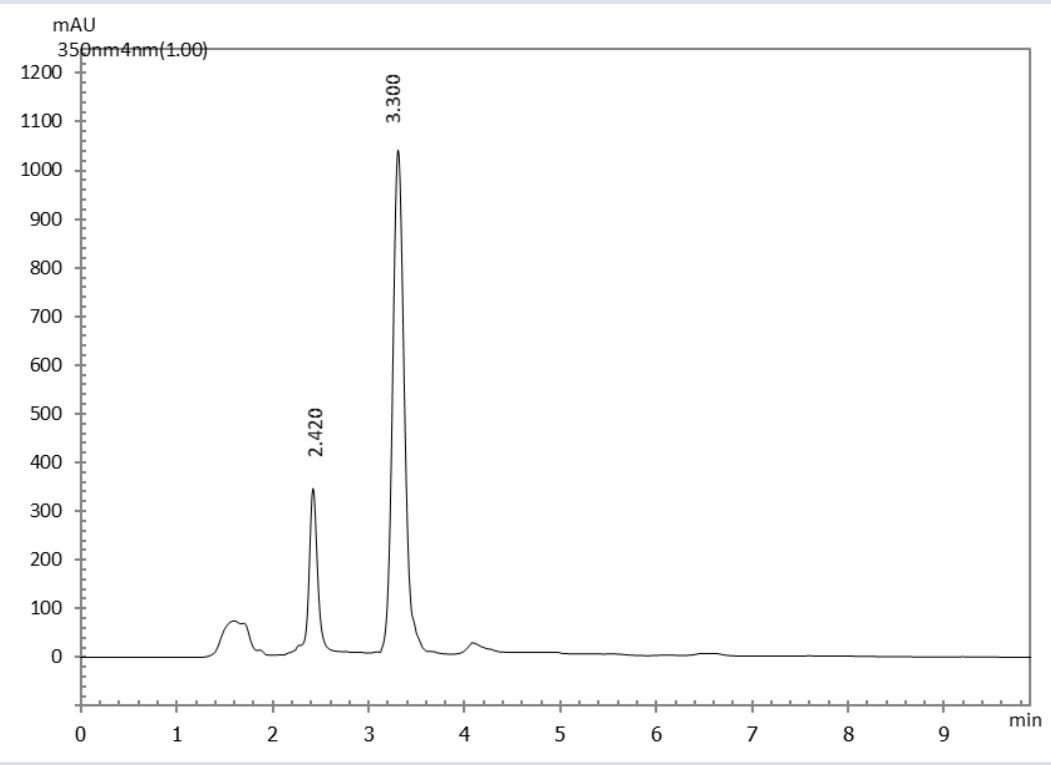

Figure 4: HPLC chromatogram of group 1 extract (control group). 


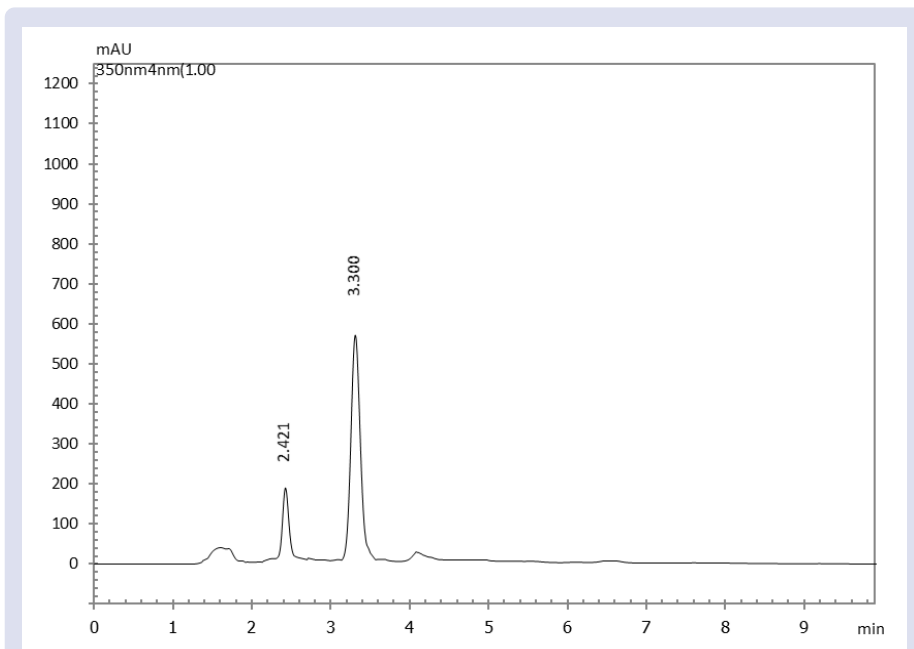

Figure 5: HPLC chromatogram of group 2 extract (pre-treated by roasting).

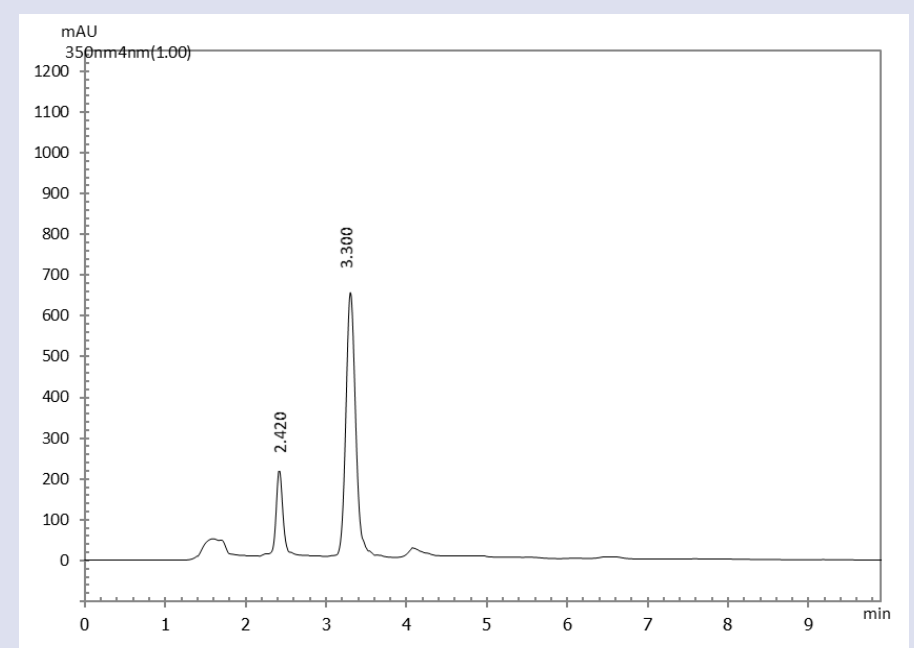

Figure 6: HPLC chromatogram of group 3 extract (pre-treated by burning).

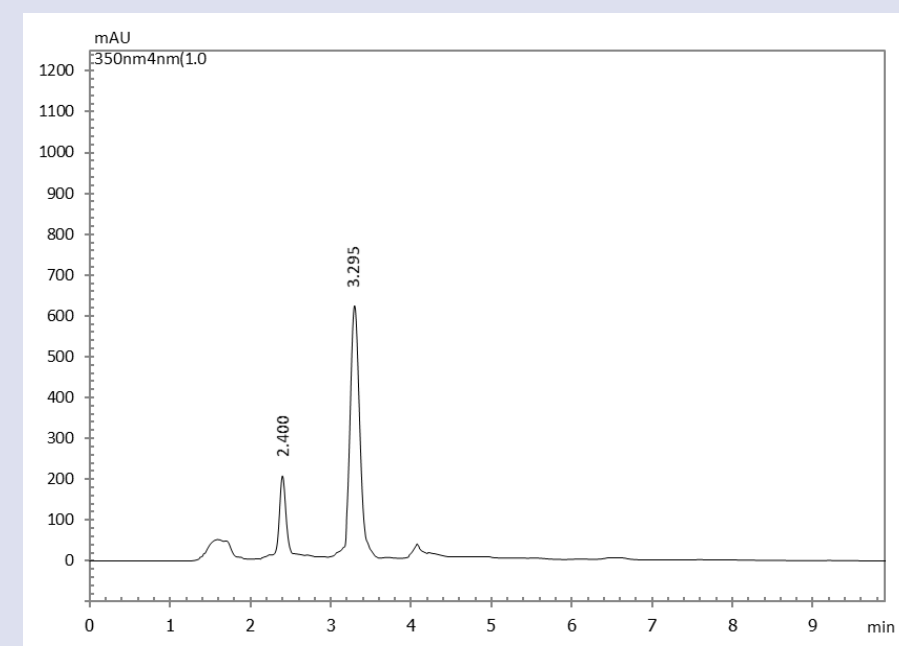

Figure 7: HPLC chromatogram of group 4 extract (pre-treated by boiling). 


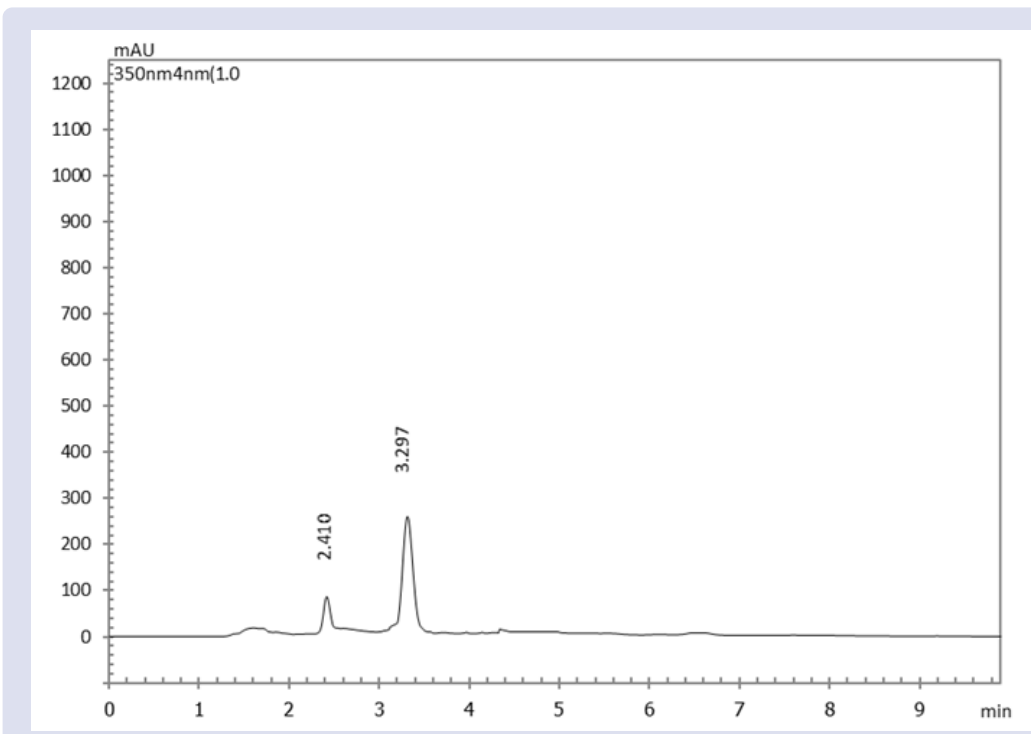

Figure 8: HPLC chromatogram of group 5 extract (pre-treated by stewing).

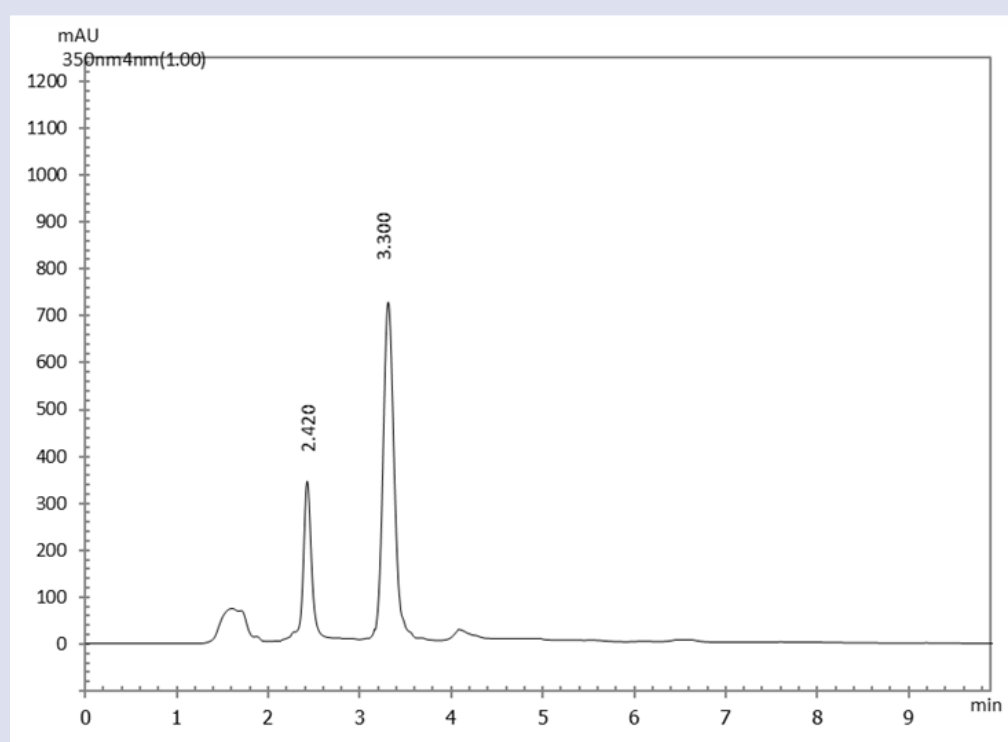

Figure 9: HPLC chromatogram of group 6 extract (pre-treated by grilling).

Table 1: Amount of colchicine in extract.

\begin{tabular}{|c|c|c|c|c|c|c|c|}
\hline \multirow[b]{2}{*}{ No } & \multirow[b]{2}{*}{ Sources } & \multicolumn{6}{|c|}{ Amount of colchicine in extract (mg/extract $1 \mathrm{~g})($ mean $\pm S D, n=3)$} \\
\hline & & $\begin{array}{l}\text { Group } 1 \\
\text { (control) }\end{array}$ & $\begin{array}{c}\text { Group } 2 \\
\text { (roasting) }\end{array}$ & $\begin{array}{l}\text { Group } 3 \\
\text { (burning) }\end{array}$ & $\begin{array}{l}\text { Group } 4 \\
\text { (boiling) }\end{array}$ & $\begin{array}{l}\text { Group 5 } \\
\text { (stewing) }\end{array}$ & $\begin{array}{l}\text { Group } 6 \\
\text { (grilling) }\end{array}$ \\
\hline 1 & $\begin{array}{l}\text { Chonburi province, wild population } \\
\text { (Jun } 15,2020 \text { ) }\end{array}$ & $3.627 \pm 0.001$ & $2.484 \pm 0.079$ & $2.601 \pm 0.023$ & $1.934 \pm 0.002$ & $1.206 \pm 0.052$ & $2.748 \pm 0.045$ \\
\hline 2 & $\begin{array}{l}\text { Surin province, cultivated farm } \\
\text { (Jun } 29,2020 \text { ) }\end{array}$ & $10.055 \pm 0.016$ & $4.682 \pm 0.073$ & $4.729 \pm 0.021$ & $5.072 \pm 0.009$ & $1.201 \pm 0.004$ & $5.669 \pm 0.055$ \\
\hline 3 & $\begin{array}{l}\text { Nakhonratchasima province, } \\
\text { wild population (Jul 13, 2020) }\end{array}$ & $8.983 \pm 0.024$ & $3.993 \pm 0.098$ & $4.428 \pm 0.023$ & $4.098 \pm 0.075$ & $2.156 \pm 0.073$ & $5.265 \pm 0.022$ \\
\hline 4 & $\begin{array}{l}\text { Sakaeo province, cultivated farm } \\
\text { (Jul 15, 2020) }\end{array}$ & $3.128 \pm 0.007$ & $1.962 \pm 0.002$ & $2.490 \pm 0.097$ & $2.113 \pm 0.006$ & $1.097 \pm 0.003$ & $2.536 \pm 0.087$ \\
\hline 5 & $\begin{array}{l}\text { Prachinburi province, wild population } \\
\text { (Jul 20, 2020) }\end{array}$ & $5.735 \pm 0.007$ & $2.850 \pm 0.002$ & $3.759 \pm 0.003$ & $3.459 \pm 0.043$ & $0.787 \pm .017$ & $4.382 \pm 0.013$ \\
\hline & Ave $($ mean \pm SD) & $6.306 \pm 2.884$ & $3.194 \pm 1.036$ & $3.601 \pm 0.951$ & $3.335 \pm 1.231$ & $1.289 \pm 0.477$ & $4.120 \pm 1.324$ \\
\hline$\% \operatorname{Rec}$ & lucing compare with control group. & & $\begin{array}{c}45.61 \pm 10.61 \\
(p=0.000)\end{array}$ & $\begin{array}{c}37.35 \pm 14.15 \\
(p=0.000)\end{array}$ & $\begin{array}{c}44.55 \pm 8.60 \\
(p=0.000)\end{array}$ & $\begin{array}{c}76.40 \pm 10.70 \\
(p=0.000)\end{array}$ & $\begin{array}{c}30.35 \pm 11.31 \\
(p=0.000)\end{array}$ \\
\hline
\end{tabular}


Table 2: Comparison between pretreatment methods.

$\begin{array}{ccc}\begin{array}{c}\text { Compare between pretreatment } \\ \text { methods }\end{array} & \begin{array}{c}\text { Mean difference of colchicine } \\ \text { content }(\mathrm{mg} / \text { extract 1 g) (mean } \pm \text { SD) }\end{array} & \begin{array}{l}\text { \% difference } \\ (\text { mean } \pm \text { SD) }\end{array} \\ \text { Roasting VS Burning } & -0.407 \pm 0.346 & -15.09 \pm 13.66 \\ \text { Roasting VS Boiling } & -0.141 \pm 0.436 & -3.58 \pm 15.95 \\ \text { Roasting VS Stewing } & 1.905 \pm 0.999 & 57.65 \pm 14.62 \\ \text { Roasting VS Grilling } & -0.926 \pm 0.514 & -29.31 \pm 15.97 \\ \text { Boiling VS Burning } & -0.266 \pm 0.371 & -12.46 \pm 15.14 \\ \text { Boiling VS Stewing } & 2.046 \pm 1.278 & 57.34 \pm 18.23 \\ \text { Boiling VS Grilling } & -0.784 \pm 0.288 & -25.80 \pm 11.21 \\ \text { Burning VS Stewing } & 2.312 \pm 0.949 & 62.91 \pm 12.91 \\ \text { Burning VS Grilling } & -0.518 \pm 0.404 & -12.29 \pm 8.12 \\ \text { Grilling VS Stewing } & 2.830 \pm 1.317 & 6.974 \\ \mathbf{0 . 0 0 0} & 0.386 \\ \mathbf{0 . 0 0 0} & 0.765 \\ \mathbf{0 . 0 0 0}\end{array}$

$(p=0.000), \quad 76.40 \pm 10.70 \% \quad(p=0.000) \quad$ and $30.35 \pm 11.31 \%(p=0.000)$, respectively. (Table 1) Comparison between methods, the result showed that the stewing was the greatest decrease of colchicine content which significantly different from other methods. $(p=0.000)$. However, the colchicine content after pre-treated by roasting, burning, boiling, and grilling were some differences but no statistically significant difference (Table 2)

\section{DISCUSSION}

This study was compared amount of colchicine before and after pretreated by roasting and burning the dried roots of Gloriosa superba $\mathrm{L}$. which following the methods from the previous study ${ }^{4}$ and boiling, stewing, and grilling the fresh roots as indicated in the National Thai Traditional Medicine Formulary B.E.2562. The result demonstrated that all five pretreatment methods significantly reduced colchicine content but did not demolish all colchicine content from the roots of Gloriosa superba L. The stewing with honey was the greatest decrease the amount of colchicine average $76.40 \pm 10.70 \%$ which significantly different from other methods. ( $p=0.000$ ). Although the roasting and boiling methods exhibited higher reduce colchicine content than the burning and grilling method. They were not significantly different.

The longer time and higher temperature of stewing method than all other pretreatment methods were reasons for the greatest reduce amount of colchicine. The stewing process was using around 2.50 hours. The range of temperature from the beginning to 15 minutes was $30-95^{\circ} \mathrm{C}$. Then temperature for two hours was $95-105^{\circ} \mathrm{C}$ and at the end of the stewing, the sample's temperature was $130^{\circ} \mathrm{C}$. The range of temperature for roasting from the beginning to the end was $30-130^{\circ} \mathrm{C}$, taking around 15-20 minutes. The boiling method used boiling DI water which constant temperature of $95-97^{\circ} \mathrm{C}$ for 20 minutes. The range of time for burning until temperature at the center of the pot reached $75^{\circ} \mathrm{C}$ using around 18-32 minutes depending on the level of fire. After burning, take 8-13 minutes to bake the pot until temperature reached $90^{\circ} \mathrm{C}$. and using around 30 minutes to cool down to room temperature. At the end of the grilling method, the temperature of samples was 120 $130^{\circ} \mathrm{C}$ and taking around 3-8 minutes/piece depending on the thickness of Gloriosa superba L., roots. In conclusion, the timing of the stewing pretreatment method takes 5 times more than all other methods. The temperature at the end of stewing method was $130^{\circ} \mathrm{C}$ as same as roasting and grilling method but higher than the boiling and burning method. The longer time and the temperature at the end of the pretreatment method $=130^{\circ} \mathrm{C}$ were two reasons for the greatest reduce amount of colchicine in the roots of Gloriosa superba L. Therefore, further research should be studied on the factors that affected the reduction of colchicine content, such as pretreatment timing and sample temperature.

This study has one difference and two accordance issues with the previous study. All samples of this study were fresh Gloriosa superba L., roots. They are different from the previous samples that used dried roots from herbal shops. However, the mean difference between the lowest and the highest of control extract was $6.927 \mathrm{mg} / \mathrm{g}$. It was consistent with the previous study that the range of colchicine content between the lowest and the highest of control extract was $7.587 \mathrm{mg} / \mathrm{g}$. In addition, the \% reduction of colchicine content after roasting compares this study and the previous study was $45.61 \pm 10.61 \%$ and $40.61 \pm 9.55 \%$. Comparison of the \% reduction of colchicine content after burning between this study and the previous study was $37.35 \pm 14.15 \%$ and $26.79 \pm 10.89 \%$. They are no significant difference between this study and the previous study of both pretreatment methods.

This study found that the range of colchicine content in the control group from cultivating farms was similar to the wild population. The range of colchicine content from cultivating farms was $3.128 \pm 0.007$ $10.055 \pm 0.016 \mathrm{mg} / 1$-g-extract and the wild population was $3.627 \pm 0.001$ $8.983 \pm 0.024 \mathrm{mg} / 1$-g-extract. The plant age, plant location, and collected season would be associated with the variable of colchicine content in the cultivated and wild population samples. All samples provided from different locations but collected at the same time of the rainy season (Jun 15 to Jul 20,2020). Therefore, the variation of colchicine content in the control samples may be associated with the plant age and the plant locations. The specific place and plant age are factors required for further study.

\section{CONCLUSION}

Roasting, burning, boiling, stewing, and grilling pretreatment methods were significantly reduced the amount of colchicine in the roots of Gloriosa superba $\mathrm{L}$. The stewing method was the greatest reduce amount of colchicine average $76.40 \pm 10.70 \%$ which significantly different from other methods. $(p=0.000)$. The roasting and boiling method exhibited a higher reduce colchicine than the burning and grilling method, but no significant difference. Therefore, all 5 pretreatment methods were the effective methods to pretreat the roots of Gloriosa superba L. prior to use as Thai herbal remedies.

\section{ACKNOWLEDGEMENTS}

The authors would like to thank Ms. Juthamas Thaksinanukorn, Ms. Parani Kaenna, Ms. Kanoklak Thaiduang, Ms. Artiwara Hirankirati for providing the roots of Gloriosa superba L. We would like to thank the laboratory staff of Faculty of Science, Ramkhamhaeng University, and staff of the Laboratory Equipment Center, Mahasarakham University for taking care the project.

\section{CONFLICTS OF INTEREST}

The authors declare no conflicts of interest.

\section{ABBREVIATIONS}

HPLC: High Performance Liquid Chromatography. 


\section{REFERENCES}

1. Maroyi A, Maesen LJG. van der. Gloriosa Superba L. (family Colchicaceae): Remedy or poison? Journal of Medicinal Plants Research. 2011;5:6112-21.

2. Bamrougratchaphaet, editors. Wat Phra Chetuphon Vimolmangklararm's marble inscription; 1832;263-4.

3. Finkelstein Y, Aks SE, Hutson JR, Juurlink DN, Nguyen P, Dubnov-Raz $\mathrm{G}$, et al. Colchicine poisoning: the dark side of an ancient drug. Clin Toxicol (Phila). 2010;48(5):407-14
4. Tandhavadhana S, Picheansoonthon C. Reduction of Colchicine Content from Radix Gloriosae Superbae Preparata. Pharmacogn J. 2019;11(2):310-4.

5. Department of Thai Traditional and Alternative Medicine, Ministry of Public Health. National Thai Traditional Medicine Formulary B.E.2562. Bangkok: Samchareon Phanich (Bangkok); 2019;210.

6. Kewscience. Plant of the world online. Gloriosa superba L. [cite 2020 Dec 14] Available from: www. powo.science.kew.org/taxon Specimen number k001104972.

\section{GRAPHICAL ABSTRACT}

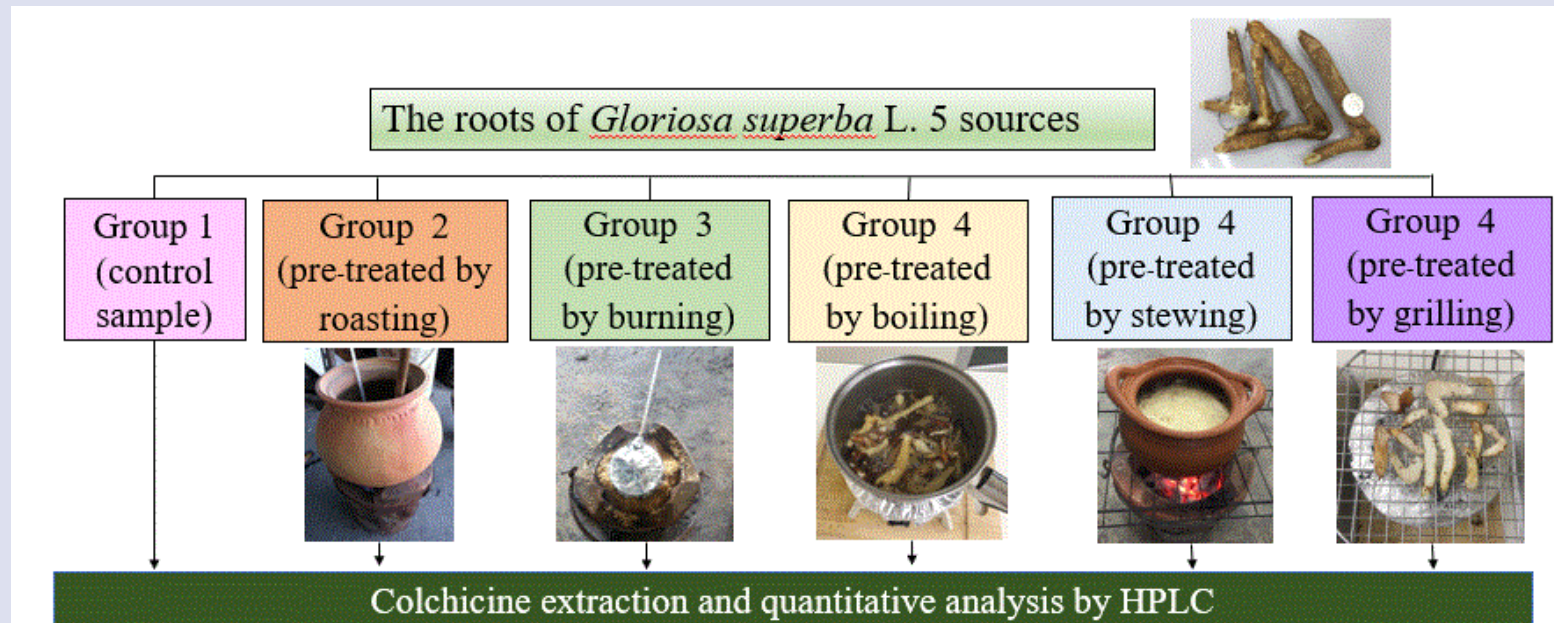

Roasting, burning, boiling, stewing, and grilling reduced colchicine by $45.61 \pm 10.61 \%(p=0.000)$, $37.35 \pm 14.15 \%(p=0.000), 44.55 \pm 8.60 \%(p=0.000), 76.40 \pm 10.70 \%(p=0.000)$ and $30.35 \pm 11.31 \%(\mathrm{p}=0.000)$

The stewing was the greatest reduce of colchicine which different from other methods. $(p=0.000)$

\section{ABOUT AUTHORS}

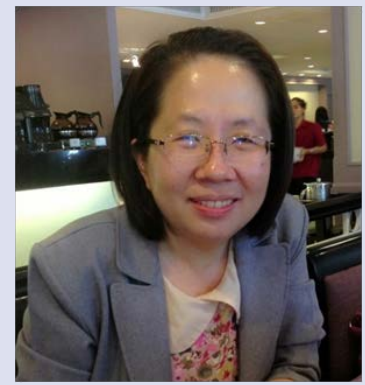

Sasithorn Tandhavadhana: Ph.D., Lecturer in Thai Traditional Medicine Department, Faculty of Science,

Ramkhamhaeng University. Her research focused on chemical constituents in medicinal plants.

Cite this article: Tandhavadhana S. Comparison of Colchicine Content in Gloriosa superba L., Root after Pretreatment by Thai Traditional Medicine Methods. Pharmacog J. 2021;13(4): 942-948. 